Accepted as: Raddats, C., Burton, J. and Ashman, R. (2015) "Resource configurations for services success in manufacturing companies", Journal of Service Management, 26 (1), 97116. Available at: http://www.emeraldinsight.com/toc/josm/26/1 (accessed on 09/02/2015). DOI: 10.1108/JOSM-12-2012-0278.

\title{
Resource configurations for services success in manufacturing companies
}

\section{Structured Abstract:}

\section{Purpose}

To investigate which resources and capabilities are most important to enable large manufacturers undergoing servitization to develop and deliver successful services.

\section{Design/methodology/approach}

A survey of 155 UK-based manufacturers provided the basis for the study. Data analysis was undertaken using confirmatory factor analysis and multiple regression.

\section{Findings}

Five constructs ('resource configurations') which enable the development and delivery of successful services and a construct to measure services performance ('Success of Services') were developed from the literature. A measurement model based on these constructs was empirically tested and verified. Two resource configurations; 'Leaders and Services Personnel' and 'Services Methods and Tools' were found to make a unique and statistically significant contribution to 'Success of Services'.

\section{Research implications/limitations}

The study highlights the importance of corporates leaders and service employees in developing and delivering success. Service-specific methods and tools are important for developing compelling customer offerings. The study demonstrates the utility of a resource-based perspective in terms of understanding the factors that enable successful services, but also exposes the limitations of using such broad measures, with common lower order resources underpinning multiple resource configurations. The study was conducted from the manufacturer's perspective, and future studies could also include the customer's perspective.

\section{Practical implications}

The research identifies important factors in developing a greater service orientation in manufacturing companies.

\section{Originality/value}


Accepted as: Raddats, C., Burton, J. and Ashman, R. (2015) "Resource configurations for services success in manufacturing companies", Journal of Service Management, 26 (1), 97116. Available at: http://www.emeraldinsight.com/toc/josm/26/1 (accessed on 09/02/2015). DOI: 10.1108/JOSM-12-2012-0278.

This is one of the first studies to develop and test a model of services success, generalizable to the population of large manufacturers.

\section{Introduction}

Manufacturers are increasingly focusing on services in order to enhance customer relationships, to develop new sources of revenue, and to resist product commoditization and parity through service-based product differentiation (Oliva and Kallenberg, 2003). The addition of services to a core product offering is often described as servitization (Vandermerwe and Rada, 1988) or service infusion (Brax, 2005). Servitization is linked to the concept of manufacturers going 'downstream', that is, identifying and exploiting opportunities in the customer's value chain (Wise and Baumgartner, 1999). To address the opportunities from servitization manufacturers are developing a range of offerings: services supporting their products (SSP), whereby the direct recipients of the services are their products (Mathieu, 2001); services that support the client's actions in relation to the supplied products (SSC) (Mathieu, 2001); solutions, which are longitudinal relational processes designed to solve strategic customer-specific problems (Storbacka, 2011). Although many benefits are associated with servitization (Ulaga and Reinartz, 2011; Gebauer et al., 2011); further investigation is required to understand which capabilities better enable manufacturers to develop and deliver successful services.

A number of exploratory studies have discussed the resources and capabilities that enable the development and delivery of successful services. For example, based on 22 case studies, Ulaga and Reinartz (2011) concluded that there were four critical resources and five capabilities which were important for success. Other studies have developed theoretical frameworks (Holmström et al., 2010; Kinnunen and Turenen, 2012). There is a need for further studies that are generalizable to the population of large manufacturers (Jacob and Ulaga, 2008). This study's objective is therefore to investigate which resources and capabilities are most important to enable a wide cross-section of large manufacturers to develop and deliver successful services. These resources and capabilities will include those required for SSP, SSC and solutions. No attempt has yet been made in the literature to rank 
Accepted as: Raddats, C., Burton, J. and Ashman, R. (2015) "Resource configurations for services success in manufacturing companies", Journal of Service Management, 26 (1), 97116. Available at: http://www.emeraldinsight.com/toc/josm/26/1 (accessed on 09/02/2015). DOI: 10.1108/JOSM-12-2012-0278.

the resources and capabilities in terms of their importance, which is the contribution of this study.

The theoretical framework adopted in this study is set out in the next section; firstly, discussing how manufacturers measure the success of their services; secondly, the resources and capabilities that enable successful services. The study identifies six constructs; 'Success of services' to measure services success; 'Industry Standing', 'Services Methods and Tools', 'Leaders and Services Personnel', 'Collaborative Approach' and 'Solution Approach' to represent the resource configurations which enable successful services. This is followed by an explanation of the study's methodology, which is based on a survey of 155 manufacturing companies. Data analysis includes the use of confirmatory factor analysis to validate the measurement model and multiple regression to assess the extent to which the resource configurations contribute to services success. The results and a discussion of the findings and implications for practitioners are then presented. The results show that only two resource configurations make unique significant contributions to 'Services Success'; 'Leaders and Services Personnel' and 'Services Methods and Tools'. The study demonstrates the importance of a manufacturer's leaders setting a services vision for their company and employing the right personnel, methods and tools to bring the vision to reality. The paper concludes with the limitations of the study and potential future research.

\section{Theoretical framework}

\subsection{Measuring the success of manufacturers' services}

Madhavaram and Hunt (2008) propose that a firm's capabilities can have a positive influence on its success, such as financial performance, competitive advantage and customer loyalty. Capabilities are defined as "socially complex, interconnected combinations of ... resources" (Madhavaram and Hunt, 2008, p. 68), whilst success in this context, is defined as how manufacturers use services to achieve their aims through differential advantage (Ulaga and Reinartz, 2011). When attempting to measure success it has been noted that financial measures, such as profitability, are often not enough. Measuring the satisfaction of key 
Accepted as: Raddats, C., Burton, J. and Ashman, R. (2015) "Resource configurations for services success in manufacturing companies", Journal of Service Management, 26 (1), 97116. Available at: http://www.emeraldinsight.com/toc/josm/26/1 (accessed on 09/02/2015). DOI: 10.1108/JOSM-12-2012-0278.

stakeholders (e.g., customers) and the firm's ability to transform, to meet new market challenges, are also discriminators of strategic performance (Chakravarthy, 1986). The servitization literature echoes this multi-faceted approach to measuring performance and suggests that manufacturers measure these factors using financial and non-financial measures (Gebauer et al., 2009). Both of these types of measures can operate at two levels; a services specific level and a company level. Thus, four measurement aspects are outlined below and utilized in Section 3.2: Measure Development.

In terms of financial measures at a services specific level, manufacturers might measure services profitability (Eggert et al., 2013; Homburg et al., 2003; Oliva et al., 2012) and services revenue (Eggert et al., 2013; Gebauer et al., 2006). These measures are however problematic, in that many manufacturers do not measure services profitability and revenue independently from that of products, particularly if services revenue does not represent a high percentage of the corporate total (Gebauer et al., 2009). Services revenue as a percentage of the corporate total is sometimes used as a measure of success, with a high percentage representing more successful services (Anticio et al., 2008; Gebauer and Fleisch, 2007; Oliva et al., 2012). However, this measure is also problematic in that a high percentage of revenue in the overall total from services might be as a result of unsuccessful products, rather than successful services. Given the problems with measuring financial performance at a servicesspecific level, the company level can be considered. In terms of financial measures at a company level, manufacturers might measure overall company profitability (Homburg et al., 2003; Gebauer, 2007), financial performance relative to competitors (Gebauer et al., 2011) or shareholder wealth creation (Fang et al., 2008). However, the impact of services on these measures is often hard to judge, making it difficult to establish a direct link between them. Perhaps less contestable, services have been found to enhance product sales (Anticio et al., 2008) and help manufacturers to break into new markets, through making products attractive to new customers (Auguste et al., 2006).

In terms of non-financial measures, at a services specific level customers might be able to judge the quality of a supplier's services (Oliva et al., 2012). Service quality is not however a unified concept, which can be delineated between 'technical' and 'functional' service quality; 
Accepted as: Raddats, C., Burton, J. and Ashman, R. (2015) "Resource configurations for services success in manufacturing companies", Journal of Service Management, 26 (1), 97116. Available at: http://www.emeraldinsight.com/toc/josm/26/1 (accessed on 09/02/2015). DOI: 10.1108/JOSM-12-2012-0278.

the former is to do with the outcome of the service (e.g., time to fix a fault) and the latter the process by which the outcome was achieved (e.g., the customer's perspective of how the fault was dealt with) (Grönroos, 1984). Services have an important role in helping companies to differentiate their products and achieve competitive advantage (Oliva and Kallenberg, 2003). Beyond the focal manufacturer, Grönroos and Helle (2010) identified joint productivity gains (JPGs) by a supplier and its customer as a means to assess mutual value creation. In terms of non-financial measures at a company level, services play a part in helping a manufacturer to enhance customer satisfaction (Homburg et al., 2003; Oliva et al., 2012), which in turn can lead to customer loyalty and retention (Gebauer et al., 2009; Oliva et al., 2012). However, difficulties exist in measuring customer satisfaction, loyalty and retention (resulting from the services experience) when a supplier has both product and services strategic business units (SBUs) providing offerings to the same customer (Gebauer et al., 2009).

\subsection{Resources and capabilities to enable successful services}

The theoretical framework recognizes the critical role of adopting a service logic for marketing (Grönroos, 2012; Vargo and Lusch, 2008) and the importance of developing the entire organizational culture around the customer (Heinonen et al., 2010) to utilize resources as efficiently as possible. Thus, the service logic literature builds on the principles of the Resource-Based View (RBV) (Barney, 1991) and Resource-Advantage (R-A) theory (Hunt and Morgan, 1995). According to the RBV firms can be viewed as bundles of resources and capabilities that provide the basis for strategic competitive advantage, with companies needing to base their strategies on the resources and capabilities best suited to their markets (Barney, 1991). Given that firms might not own all the resources that confer competitive advantage, the RBV is not wholly appropriate to servitizing manufacturers (Kindström and Kowalkowski, 2014). We therefore draw on R-A theory, according to which firms seek to develop capabilities by combining resources in order to achieve superior financial performance and comparative advantage over rivals (Hunt et al., 2006). A hierarchical classification is a valuable approach to studying capabilities and resources: two or more lower order resources combine and interact with each other to produce valued market 
Accepted as: Raddats, C., Burton, J. and Ashman, R. (2015) "Resource configurations for services success in manufacturing companies", Journal of Service Management, 26 (1), 97116. Available at: http://www.emeraldinsight.com/toc/josm/26/1 (accessed on 09/02/2015). DOI: 10.1108/JOSM-12-2012-0278.

offerings, described as interconnected operant resources by Madhavaram and Hunt (2008). We term these resource components in this paper.

Madhavaram and Hunt (2008) classify lower order resources as operand or operant; operand resources are typically financial (e.g., being able to develop large-scale service facilities), physical (e.g., being the OEM of a product) and legal (e.g., having patents on product technology). Operant resources are typically human (e.g., skilled service engineers), organizational (e.g., having a services culture), informational (e.g., having knowledge of customers' operational processes) and relational (e.g., establishing, developing and maintaining relationships with customers and other partners). Table 1 sets out the lower order resources which combine to create the resource components, which have been sourced from the extant literature. For example, a manufacturer's 'reputation' may come from its history of being a product manufacturer (products are a 'physical' resource) and its ability to demonstrate customer value (an 'organizational' resource). Resource components can be categorized as those which are common success factors for all firms and those which are specific to servitizing firms. Whilst a number of resource components, such as knowledge management, reputation, track record, partnering with other companies appear important to all firms, those that are critical to servitizing firms typically concern the transition from a product to service provider. These include corporate leaders driving this transformation and the organization developing a service-focused culture and appropriate methodologies and tools which can create differentiated offerings. Those resource components that appear to be most applicable to servitized firms are identified in Table 1.

\section{Table 1 here}

To develop meaningful concepts to test within a theoretical model the authors used their knowledge of the literature to create five resource configurations (Borch et al., 1999), based on combining related resource components. The legitimacy of these resource configurations was supported though discussions with managers from the population. Each resource configuration highlights an important approach to how manufacturers create servitization success and is explained below. 
Accepted as: Raddats, C., Burton, J. and Ashman, R. (2015) "Resource configurations for services success in manufacturing companies", Journal of Service Management, 26 (1), 97116. Available at: http://www.emeraldinsight.com/toc/josm/26/1 (accessed on 09/02/2015). DOI: 10.1108/JOSM-12-2012-0278.

The first resource configuration identified is 'Industry Standing'. We define Industry Standing as the regard in which a manufacturer is held by customers, based on a number of intangible issues which can positively impact the success of its services. A manufacturer's engineering heritage can provide it with know-how that might not be available to pure service companies, so enhancing its market credibility (Johnstone et al., 2009). This heritage provides customers with the assurance that the manufacturer has knowledge of the relevant technologies and the skills to develop service solutions around them (Ceci and Prencipe, 2008). Corporate reputation has been shown to have a positive impact on customers' perception of trust in a supplier (Keh and Xie, 2008), and is valuable for customers in assessing the value of a manufacturer's services (Hansen et al., 2008). A successful track record of services delivery can enhance this reputation (Caceres and Paparoidamis, 2007), whilst developing a services culture is often a pre-requisite for a successful and credible services business (Jacob and Ulaga, 2008; Kinnunen and Turunen, 2012; Ostrom et al., 2010). This analysis leads to the first hypothesis:

\section{H1: A positive association exists between a manufacturer's Industry Standing and its services success.}

The second resource configuration is termed 'Services Methods and Tools', which is defined as the knowledge-based capabilities, processes and organizational structures which facilitate successful service development and delivery. It has been recognized that firms with significant financial capabilities will develop economies of scale (Ceci and Masini, 2011; Ceci and Prencipe, 2008). For example, a manufacturer might have a high volume services capability such as a large network of distribution centers which cannot be easily replicated by competitors (Auguste et al., 2006). The product-related knowledge manufacturers have could be valuable in terms of developing new services (Ulaga and Reinartz, 2011), whilst knowledge management can facilitate effective sharing of this information around the company (Johnstone et al., 2009; Lee and Lee, 2007). Sawhney (2006) argues that organizations need to develop 'project capabilities' alongside their functional and strategic capabilities. Thus, in order to achieve this, organizations may need to consider the strategic 
Accepted as: Raddats, C., Burton, J. and Ashman, R. (2015) "Resource configurations for services success in manufacturing companies", Journal of Service Management, 26 (1), 97116. Available at: http://www.emeraldinsight.com/toc/josm/26/1 (accessed on 09/02/2015). DOI: 10.1108/JOSM-12-2012-0278.

orientation of their service infrastructure to reflect on whether they support a culture of customer centricity. Developing services methodologies, which are more efficient than customers' own, or those from competitors also appears to be a key capability (Auguste et al., 2006; Storbacka, 2011). Development of service-based IT tools can provide a manufacturer with new capabilities, e.g., monitoring equipment as part of a preventative maintenance service (Allmendinger and Lombreglia, 2005). Thus, the second hypothesis is:

H2: A positive association exists between the superiority of a manufacturer's Services Methods and Tools and its services success.

The third resource configuration is termed 'Leaders and Service Personnel', which we define as the service orientation of a manufacturer's senior managers and services personnel. A manufacturer's senior managers have a crucial role in terms of setting the services vision for the organization and communicating this to employees, since services are sometimes not viewed as a core activity within a manufacturer (Anticio et al., 2008). Corporate leaders must also have extensive knowledge of their customers' business challenges, with this particularly important in a services environment (Gebauer et al., 2010). Services personnel need a range of skills including technical expertise (Gounaris, 2005), which may also be required on products from other suppliers to enable systems integration if required by customers (Ceci and Masini, 2011; Raddats and Easingwood, 2010). Manufacturers need effective human resource policies which enable the recruitment of workers with the correct skill sets and the ability to train and retain them in the business (Neu and Brown, 2005). This analysis leads to the next hypothesis:

H3: A positive association exists between the service orientation of a manufacturer's Leaders and Services Personnel and its services success.

The fourth resource configuration is termed 'Collaborative Approach'; the ability to work collaboratively with customers and other partners. As manufacturers develop services which are closely aligned to the customer's operational processes (Araujo and Spring, 2006), the ability to work collaboratively with customers and other partners becomes paramount, since 
Accepted as: Raddats, C., Burton, J. and Ashman, R. (2015) "Resource configurations for services success in manufacturing companies", Journal of Service Management, 26 (1), 97116. Available at: http://www.emeraldinsight.com/toc/josm/26/1 (accessed on 09/02/2015). DOI: 10.1108/JOSM-12-2012-0278.

manufacturers may not be able to master all the relevant service activities internally (Gebauer et al., 2013; Gebauer et al., 2010). Capabilities are thus developed internally, externally or in a mixed way (Paiola et al., 2013). In particular, a manufacturer's service employees need to behave as though they are part of the customer's 'team' (Homburg et al., 2003) and may have roles encompassing both intra- and inter-firm functions (Storbacka, 2011). Team working not only means working collaboratively with customers but also partners, such as other product suppliers (Windahl et al., 2004) and sub-contractors (Vandaele and Gemmel, 2004). In this regard, the importance of firms in the network has been noted for manufacturers undergoing servitization (Henneberg et al., 2013: Storbacka, 2011). Subsequently, the fourth hypothesis is:

\section{H4: A positive association exists between the extent of a manufacturer's Collaborative} Approach and its services success.

The fifth resource configuration is termed 'Solution Approach'. A solution can be defined as an integrated combination of customized products and services, which allow customers to get a better outcome than they would have from the individual components of the solution (Sawhney, 2006). Thus, a Solution Approach is one that enables manufacturers to provide solutions either directly to customers or via channel partners. Offering solutions requires a strong appreciation of customers' business drivers and needs (and ideally those of their end users or customers) and an ability to tailor solutions to meet those needs (Ceci and Masini, 2011; Gebauer et al., 2010). The ability to offer solutions requires trusting relationships with customers, since there is likely to be greater sharing of sensitive information between the parties (Brax and Jonsson, 2009; Rauyruen and Miller, 2007). Trust between customer and supplier may develop through the manufacturer avoiding over-selling its capabilities (Gebauer et al., 2010). Thus, manufacturers need both technical capability and impartiality when specifying solutions (Raddats and Burton, 2014). Distributors can be an effective means to provide solutions to an aftermarket, where they have greater customer knowledge than the manufacturer (Ulaga and Reinartz, 2011). Hypothesis 5 is therefore: 
Accepted as: Raddats, C., Burton, J. and Ashman, R. (2015) "Resource configurations for services success in manufacturing companies", Journal of Service Management, 26 (1), 97116. Available at: http://www.emeraldinsight.com/toc/josm/26/1 (accessed on 09/02/2015). DOI: 10.1108/JOSM-12-2012-0278.

H5: A positive association exists between the effectiveness of a manufacturer's Solution Approach and its services success.

Figure 1 summarizes this conceptual framework which guided the study.

\section{Figure 1 here}

\section{Methodology}

\subsection{Data Collection and Sampling}

The unit of analysis for the study was the company or SBU. A SBU is a relatively autonomous unit controlling a number of its own functions, e.g., marketing, manufacturing (Homburg et al., 1999). Focusing on SBUs is more appropriate in larger companies, because different SBUs in the same company may have different measures of how they create successful services. Using Churchill and Iacobucci's (2005) sampling approach the target population was set as large business-to-business (B2B) manufacturers in the United Kingdom (standard industrial classification [SIC] 10-35 [UK SIC of Economic Activities, 2003]), which had an annual turnover of $£ 5$ million and above. Company details for 642 organizations were purchased from a reputable provider of B2B lists (Market Location Ltd) in order to reduce coverage error. See Appendix A for details of companies in the study by sector.

The survey instrument was created both on paper and online using a similar layout to avoid response bias attributable to the media ('unimode construction', Dillman, 2007). The survey instrument was pilot tested with three managers from the population, who were not part of the final sample. Minor changes were made to improve survey layout and readability. Before distribution of the survey, calls were made to each manager on the list to ensure they were able to complete it, i.e., they were knowledgeable about their organization's services or whether there was someone else more appropriate in the organization. The self-administered survey was distributed (one per company or SBU) by post to predominantly Marketing 
Accepted as: Raddats, C., Burton, J. and Ashman, R. (2015) "Resource configurations for services success in manufacturing companies", Journal of Service Management, 26 (1), 97116. Available at: http://www.emeraldinsight.com/toc/josm/26/1 (accessed on 09/02/2015). DOI: 10.1108/JOSM-12-2012-0278.

Managers, but in a few cases we were directed to the 'Service Manager' as the key informant. Two follow-up approaches were made to maximize the response and minimize non-response bias (Churchill and Iacobucci, 2005): firstly, via a postcard or e-mail and subsequently by telephone. The telephone follow-up in particular increased the response rate and helped to identify reasons for non-response (predominantly recipients did not have time to complete the survey). In order to detect possible non-response error, an independent samples t-test was applied to early and late responses (Armstrong and Overton, 1977). Early responses were considered to be those received before telephone follow-up (98) and late responses those received after telephone follow-up (57). No statistical differences were found, so nonresponse error was not considered to be a problem. The groups were treated as one sample for subsequent analyses $(\mathrm{n}=155)$. A response rate of $24 \%$ is reasonable for a B2B population (Paxson, 1992).

\subsection{Measure Development}

Using de Vaus' (2002) approach to survey design, indicators and items were taken from the servitization and new product/service development literature. The item development process involved item generation and refinement (Churchill, 1979). A pool of items was generated or adapted by the authors using their expertise and knowledge of prior research in this area. Items were refined through extensive and iterative discussions with ten managers from the population. Managers involved in this process were from different sectors of the population to ensure consistent meaning of items across all respondents, with these sectors indicated in Appendix A. Two academic experts were asked to assess the face validity of the items in relation to the constructs, in order to assess the parsimony of the refined item pool (Churchill, 1979).

21 items were used to measure six constructs. Some adaptation and development of the scale items used was needed to refine questions to the phenomena under study. The success of a manufacturer's services was operationalized using a four item construct, which included two financial items (item codes SoS1 and SoS2) and two non-financial items (item codes SoS3 and SoS4). Five additional constructs were developed to determine the most important 
Accepted as: Raddats, C., Burton, J. and Ashman, R. (2015) "Resource configurations for services success in manufacturing companies", Journal of Service Management, 26 (1), 97116. Available at: http://www.emeraldinsight.com/toc/josm/26/1 (accessed on 09/02/2015). DOI: 10.1108/JOSM-12-2012-0278.

resource configurations to enable the development and delivery of successful services, namely Industry Standing (three items), Services Methods and Tools (three items), Leaders and Personnel (four items), Collaborative Approach (four items) and Solution Approach (three items). Likert-type scales were used for all six constructs, with a seven-item response format; 1 = "strongly disagree", 7 = "strong agree" and 4 = "neither agree nor disagree" (de Vaus, 2002). Approaches to control for common method variance are important (Lindell and Whitney, 2001). Firstly, to avoid over-justification, respondents were unaware of the relationships under investigation; secondly, although consideration was given to randomly ordering items, ultimately the decision was taken to group them for particular topics in order to reduce respondents' cognitive burden during survey completion (Dillman, 2007). Table 2 provides an overview of the six constructs, items within each construct and their sources.

\section{Table 2 here}

\subsection{Validation of Measures}

Confirmatory factor analysis (CFA) was used to validate the measurement model. CFA can help in understanding how strongly the observed variables link with specified latent variables (Byrne, 2010). The measurement model was tested to check that meaningful theoretical relationships existed: AMOS 20 was used for this. The fit indices to check the fit of the model included the $\chi^{2}$, relative $\chi^{2}$ (CMIN/DF), root mean square residual (RMR), Non-Normed Fit Index (NNFI), comparative fit index (CFI), root mean square error of approximation (RMSEA) and normed fit index (NFI). A table of thresholds for each of these indices is presented in Table 3.

\section{Table 3 here}

Fit statistics for the model specified and tested using CFA indicated that the six construct model has reasonable fit $\left(\chi^{2}=301.998, \mathrm{df}=174, \mathrm{p}=0.000\right.$, Relative $\chi^{2}=1.766$, RMR $=$ $.004, \mathrm{RMSEA}=.071, \mathrm{CFI}=.919$ and NNFI $=.901)$. The value for the $\chi^{2}$ did not meet the required threshold, but this statistic is well known for its sensitivity to Type II error (Bollen and Long, 1993; Blunch, 2008; Schumaker and Lomax, 2010) and so was analyzed with the 
Accepted as: Raddats, C., Burton, J. and Ashman, R. (2015) "Resource configurations for services success in manufacturing companies", Journal of Service Management, 26 (1), 97116. Available at: http://www.emeraldinsight.com/toc/josm/26/1 (accessed on 09/02/2015). DOI: 10.1108/JOSM-12-2012-0278.

other fit statistics. Whilst some of the other model fit indices did not reach the accepted thresholds presented above (RMSEA and NNFI) the size of the sample $(n=155)$ is believed to be a key issue in this and therefore the analysis continued. Construct loadings within the measurement model are sufficient, with 20 of 21 standardized estimates (SEs) exceeding the minimum value of 0.5 (Hair et al., 2006). Taking into consideration that the sample size used in this study is relatively small; the results indicated here confirm the efficiency of the measurement model.

Reliability was examined used Cronbach's Alpha coefficient $(\alpha)$, which has a suggested threshold of 0.7 (Nunnally, 1978) or 0.6 where scales have few items (Pallant, 2007). Five out of the six constructs reached the 0.7 threshold whilst the other (Solution Approach) reached the 0.6 threshold. Convergent validity was also tested using the SEs for each item by calculating the average variance extracted (AVE). This is done by taking the sum of the squared SEs and then dividing this value by the number of items in each construct. AVE values are recommended to be above 0.5 (Hair et al., 2006), with four of the six constructs above this threshold (Success of Services, Industry Standing, Leaders and Personnel, Collaborative Approach). The AVE value for 'Services Methods and Tools', was only just below 0.5 and the value for 'Solution Approach' is moderately below 0.5. However, Hatcher (1994) found that AVE is a fairly conservative measure and values can be below 0.5 even if construct reliability is acceptable. Therefore, it was decided to continue with the analysis using six constructs. Table 4 documents these statistics.

\section{Table 4 here}

\section{Results}

Multiple regression was used to assess the extent to which five resource configurations predict services success. Preliminary analyses were conducted to ensure that data were suitable for this analysis. Multicollinearity was assessed by confirming that all variable correlations were below 0.8 and that tolerance and variance inflation factors were within acceptable guidelines (Field, 2009). Outliers, normality, linearity and homoscedasticity were 
Accepted as: Raddats, C., Burton, J. and Ashman, R. (2015) "Resource configurations for services success in manufacturing companies", Journal of Service Management, 26 (1), 97116. Available at: http://www.emeraldinsight.com/toc/josm/26/1 (accessed on 09/02/2015). DOI: 10.1108/JOSM-12-2012-0278.

assessed by inspecting the 'Normal Probability Plot of the Regression Standardized Residual' and the 'Scatterplot', with no violations detected (Field, 2009).

A forced (or standard) multiple regression using SPSS 20 was conducted, i.e., all independent variables were entered into the model simultaneously (Field, 2009). Each independent variable (IV) was evaluated in terms of predictive power, compared to the other IVs in the model. The variables used in the analysis were the summated scales of each construct tested in the measurement model (presented in Table 4). Summated scales are considered an effective way to reduce measurement error, since the analysis does not rely on one variable to represent a concept (Hair et al., 2006). Thus, the model comprised five IVs (summated scores for the resource configurations which help manufacturers to develop and deliver services) and one dependent variable (DV) (summated score for the 'Success of Services' construct). To be generalizable to the population multiple regressions require an adequate sample size, with a minimum of 100 observations usually needed (Hair et al., 2006). Equally, a ratio of 20 observations to each variable is usually sought (Hair et al., 2006). These requirements were met for this sample.

The total variance explained by the model as a whole $\left(\mathrm{R}^{2}\right)$ was $35.9 \%, F(5,149)=16.72, p<$ .001. Only two resource configurations make unique significant contributions to 'Success of Services'; 'Leaders and Personnel' $(\beta=.21, p \leq .05)$ and 'Services Methods and Tools' $(\beta=$ $.2, p \leq .05)$. The remaining resource configurations made positive, but non-significant, contributions to 'Services success'; 'Industry Standing' $(\beta=.2, p>.05)$, 'Collaborative Approach' $(\beta=.11, p>.05)$. 'Solution Approach' $(\beta=.01, p>.05)$. Thus, 'Leaders and Personnel', Services Methods and Tools' and 'Industry Standing' all made similar contributions to services success, although only the first two were unique and statistically significant. Based on these results, Table 5 presents a summary of the study's hypotheses.

\section{Table 5 here}


Accepted as: Raddats, C., Burton, J. and Ashman, R. (2015) "Resource configurations for services success in manufacturing companies", Journal of Service Management, 26 (1), 97116. Available at: http://www.emeraldinsight.com/toc/josm/26/1 (accessed on 09/02/2015). DOI: 10.1108/JOSM-12-2012-0278.

\section{Discussion and contribution}

\subsection{Theoretical contribution}

The study's objective was to establish which resources and capabilities are most important to enable the development and delivery of successful services. To achieve this objective a theoretical model based on resource configurations was developed and empirically tested. The theoretical contributions of the study align to this objective.

Firstly, the study identified two resource configurations which make a unique and significant contribution to services success. These resource configurations have the highest number of resource components which are applicable to servitizing firms (see Table 1), so it is perhaps not surprising that they are pre-eminent in creating successful services. The first resource configuration that makes a unique and significant contribution to services success is the service orientation of a manufacturer's leaders and service personnel. Setting a services vision for the company and implementing a plan to achieve this vision appears particularly important. Most manufacturers start from a product orientation, so this study supports Anticio et al. (2008) in the importance of senior managers' commitment to growing the services business and leadership in terms of increasing service orientation (Gebauer et al., 2010). The pre-eminence of leaders driving the transformation to services is not surprising since there are often many obstacles preventing this transformation, described as the 'service paradox' (Gebauer et al., 2005). Overcoming this paradox requires a belief in the economic potential of services and an acceptance of some degree of risk (Gebauer et al., 2005). However, it would seem that services leadership is more necessary for developing and delivering SSC than SSP, since the transformation is more radical, with a greater need to manage conflicting demands of product and service businesses (Galbraith, 2002). The importance of services staff is also noteworthy in terms of a manufacturer developing a greater service orientation through its human resource management policies (Gebauer et al., 2010). Services staff need to have both technical expertise and customer empathy, supporting Neu and Brown (2005). 
Accepted as: Raddats, C., Burton, J. and Ashman, R. (2015) "Resource configurations for services success in manufacturing companies", Journal of Service Management, 26 (1), 97116. Available at: http://www.emeraldinsight.com/toc/josm/26/1 (accessed on 09/02/2015). DOI: 10.1108/JOSM-12-2012-0278.

The second resource configuration that makes a unique and significant contribution to services success is the manufacturer's service methods and tools. Having the ability to offer customers compelling service offerings is ultimately what will determine whether a manufacturer is successful in its servitization transition. Compelling offering might be services that replace or supplement customer processes such product operations and maintenance or offering services which are distinct from those of competitors (August et al., 2006). Sharing the knowledge of how a particular service was developed and delivered throughout the company is critical in a service environment, since developing repeatable and scalable processes is an important aspect of successful service and solution provision (Storbacka, 2011). This finding therefore supports the importance of effective knowledge management during servitization (Lee and Lee, 2007).

Secondly, the study has demonstrated the value of R-A theory (Hunt and Morgan, 1995) in terms of the lower order resources required for successful servitization. The resource configurations which create a significant and unique contribution to service success are based on four lower order resources; financial, human, informational and organizational. 'Services Methods and Tools' requires investment in suitable information and communication technology (ICT) (financial), methodologies are required to manage how service implementations are undertaken (organizational), whilst this knowledge needs to be shared within the organization to enable replication and scaling (informational). 'Leaders and Personnel' are clearly 'human' resources. Corporate leaders need to understand customers' business challenges and how their product and service offerings might address them. Service employees need knowledge of the company's products, both technical knowhow and an appreciation of how they work in the customer's operational environment (informational). Finally, to retain the 'best' leaders and service employees requires competitive remuneration packages (financial). As can be seen from Table 1, human, informational and organizational lower order resources are also the 'building blocks' of the other resource configurations which did not have a unique and significant contribution to services success, e.g., 'Industry Standing' and 'Collaborative Approach'. Evidence from this study shows that whilst 'Industry Standing' makes a contribution to services success equal in magnitude to that of 'Leaders and Services Personnel' and 'Services Methods and Tools', the contribution is not 
Accepted as: Raddats, C., Burton, J. and Ashman, R. (2015) "Resource configurations for services success in manufacturing companies", Journal of Service Management, 26 (1), 97116. Available at: http://www.emeraldinsight.com/toc/josm/26/1 (accessed on 09/02/2015). DOI: 10.1108/JOSM-12-2012-0278.

unique and this is likely to be because some of the underlying lower order resources are common. For example, whilst 'Industry Standing' might superficially appear to be distinct from 'Services Methods and Tools', organizational resources include competences, controls, policies and culture (Hunt and Morgan, 1995), which underpin them both. Thus, the scope of lower order resources is very broad, meaning that it can be problematic to isolate specific ones which can be aligned uniquely to each resource configuration.

Thirdly, the insignificant contributions of 'Collaborative Approach' and 'Solution Approach' to services success are also noteworthy, with this not surprising given there were no servicesspecific resource components identified in either (see Table 1). A collaborative approach with customers is in line with the basic premises of service logic and relationship marketing, whereby companies should have a long-term relational orientation as a normative goal (Grönroos, 2012; Morgan and Hunt, 1994). However, the 'Collaborative Approach' resource configuration included resource components which reflect the requirement to work with partners, such as other product suppliers, in order to provide multi-vendor offerings (Raddats and Burton, 2014; Windahl et al., 2004). It is likely that for some manufacturers, whose focus is supplying their own products, relationships with other suppliers are less critical than with customers, therefore the contribution of this resource configuration to services success might be lower than if the resource configuration solely concerned customer relationships. In terms of solutions, it might be that solutions are not important to many manufacturers. Solution provision is a firm-wide initiative which requires a completely different logic to that of a product business (Storbacka, 2011), with this perhaps a step that most manufacturers are unwilling or unable to undertake. It might also be the case that the term 'solution' is not well understood, with differing interpretations of what it means (Nordin and Kowalkowski, 2010). This would lead to some ambiguity as to whether it was an important resource configuration for a manufacturer or not. However, an alternative explanation is that the Solution Approach resource configuration needs further resource components to fully encapsulate it (e.g., the ability to customize and integrate product/service offerings).

\subsection{Implications for management}


Accepted as: Raddats, C., Burton, J. and Ashman, R. (2015) "Resource configurations for services success in manufacturing companies", Journal of Service Management, 26 (1), 97116. Available at: http://www.emeraldinsight.com/toc/josm/26/1 (accessed on 09/02/2015). DOI: 10.1108/JOSM-12-2012-0278.

Services can play a significant role in helping manufacturers to develop new business, differentiate products and improve customer retention. There are a number of elements that managers within manufacturers can address to develop their services, with this study suggesting that two are most important; 1) a company's leaders and services personnel and 2) its services methods and tools. The role of senior managers in leading a transition to a more service-focused business is essential. Most manufacturers have traditionally had a productorientation, and for a service orientation to develop requires many changes within the organization including greater prioritization of services within the business. This could potentially include the recruitment of new staff and possible re-configuration of the organization, to create a dedicated services SBU. Companies need to recruit, train and retain service experts within the organization who have product-related technical skills and possess knowledge of how these products work in the customer's operational environment. These can be described as 'T-shaped' skills (Lee and Lee, 2007), encompassing a high depth and breadth of product knowledge.

To offer compelling service offerings manufacturers need to develop suitable methods and acquire service-related tools. These methods and tools might be applicable at the implementation stage of a project, providing technical support or taking on activities and processes outsourced by customers, such as product operations and maintenance. In all cases the aim is be able to develop and deliver services that are more cost effective and/or differentiated than what customers or competitors can offer. For example, many companies in the ICT sector have set up centers of excellence (often off-shored to lower cost countries) to deliver some SSC. Whilst this approach might not be appropriate for all manufacturers, in many cases servitization will involve going beyond simply offering a suite of SSP, but developing SSC, which necessarily involves more collaborative relationships with customers.

\subsection{Research limitations and future directions}

This study involved cognitive-based measures to assess managerial perceptions of key constructs. Future research could assess secondary data such as financial reports and internally documented KPIs, in order to verify the relative success resulting from the 
Accepted as: Raddats, C., Burton, J. and Ashman, R. (2015) "Resource configurations for services success in manufacturing companies", Journal of Service Management, 26 (1), 97116. Available at: http://www.emeraldinsight.com/toc/josm/26/1 (accessed on 09/02/2015). DOI: 10.1108/JOSM-12-2012-0278.

servitization process that a manufacturer has followed. We do not however believe that performance can solely be assessed by using direct financial measures such as service revenue, since the benefits of services extend much further to include product differentiation, product revenue and customer retention. Equally, this study only addresses the suppliers' perspective and future studies could therefore consider which resource configurations customers believe to be important in a servitized manufacturer.

Despite being one of the largest studies carried out on this topic, testing all the constructs in a full structural equation model was not possible because the sample size was too small (over 200 responses would be needed for a model of this complexity - Hair et al., 2006). Future studies could explore this topic with a larger sample, which would allow an appreciation of the most important resource configurations for different sectors. Equally, the construct 'Solution Approach' was not entirely optimal in terms of its reliability and validity. Future studies could therefore develop and refine the components that comprise this resource configuration. 
Accepted as: Raddats, C., Burton, J. and Ashman, R. (2015) "Resource configurations for services success in manufacturing companies", Journal of Service Management, 26 (1), 97116. Available at: http://www.emeraldinsight.com/toc/josm/26/1 (accessed on 09/02/2015). DOI: $10.1108 / J O S M-12-2012-0278$.

\section{References}

Allmendinger, G. and Lombreglia, R. (2005), "Four strategies for the age of smart services", Harvard Business Review, Vol. 83 Iss. 10, pp. 131-145.

Anticio, M., Moenaert, R., Lindgreen, A. and Wetzels, G. (2008), “Organizational antecedents to and consequences of service business orientations in manufacturing companies", Journal of Academy of Marketing Science, Vol. 36, pp. 337-358.

Araujo, L. and Spring, M. (2006), "Services, products, and the industrial structure of production", Industrial Marketing Management, Vol. 35 Iss. 7, pp. 797-805.

Armstrong, J. and Overton, T. (1977), "Estimating nonresponse bias in mail surveys", Journal of Marketing Research, Vol. 14, pp. 396-402.

Auguste, B., Harmon, E. and Pandit, V. (2006), "The right service strategies for product companies", The McKinsey Quarterly, Vol. 1, pp. 40-51.

Barney, J. (1991), "Firm resources and sustained competitive advantage", Journal of Management, Vol. 17 No. 1, pp. 99-120.

Bentler, P. (1990), "Comparative fit indexes in structural models", Psychological Bulletin, Vol. 107 No. 2, pp. 238-246.

Blunch, N. (2008), Introduction to structural equation modelling using SPSS and AMOS, Sage Publications, London.

Bollen, K. and Long, J. (1993) Testing Structural Equation Models, Sage Publications, Newbury Park, California.

Borch, O., Huse, M. and Senneseth, K. (1999), "Resource configuration, competitive strategies, and corporate entrepreneurship: An empirical examination of small firms", Entrepreneurship Theory and Practice, Vol. 24 Iss. 1, pp. 49-70.

Brax, S. (2005), “A manufacturer becoming service provider - challenges and a paradox", Managing Service Quality, Vol. 15 No. 2, pp. 142-155.

Brax, S. and Jonsson, K. (2009), "Developing integrated solution offerings for remote diagnostics. A comparative case study of two manufacturers", International Journal of Operations and Production Management, Vol. 29 No. 5, pp. 539-560.

Byrne, B. (2010) Structural equation modelling with AMOS; basic concepts, applications, and programming (2nd ed.), Routledge, London.

Caceres, R. and Paparoidamis, N. (2007), "Service quality, relationship satisfaction, trust, commitment and business-to-business loyalty", European Journal of Marketing, Vol. 41 No. 7/8, pp. 836-867.

Ceci, F. and Masini, A. (2011), "Balancing specialized and generic capabilities in the provision of integrated solutions", Industrial and Corporate Change, Vol. 20 Iss. 1, pp. 91-131.

Ceci, F. and Prencipe, A. (2008), "Configuring capabilities for integrated solutions: Evidence from the IT sector", Vol. 15 No. 3, pp. 277-296. 
Accepted as: Raddats, C., Burton, J. and Ashman, R. (2015) "Resource configurations for services success in manufacturing companies", Journal of Service Management, 26 (1), 97116. Available at: http://www.emeraldinsight.com/toc/josm/26/1 (accessed on 09/02/2015). DOI: 10.1108/JOSM-12-2012-0278.

Chakravarthy, B. (1986), "Measuring strategic performance", Strategic Management Journal, Vol. 7 No. 5, pp. 437-458.

Churchill, G. (1979), “A paradigm for developing better measures of marketing constructs", Journal of Marketing Research, Vol. 16, pp. 64-73.

Churchill, G. and Iacobucci, D. (2005), Marketing research: Methodological foundations (9th ed.), South-Western, Mason, Ohio.

de Vaus, D. (2002), Surveys in social research (5th ed.), Allen \& Unwin, St. Leonards, NSW.

Dillman, D. (2007), Mail and internet surveys. The tailored design method (2nd ed.), Wiley, Hoboken, NJ.

Easingwood, C., Moxey, S. and Capleton, H. (2006), "Bringing high technology to market: Successful strategies employed in the worldwide software industry", Journal of Product Innovation Management, Vol. 23 No. 6, pp. 498-511.

Eggert, A., Hogreve, J., Ulaga, W. and Muenkhoff, E. (2013), "Revenue and profit implications of industrial service strategies", Journal of Service Research, available at: doi: $10.1177 / 1094670513485823$ (accessed $14^{\text {th }}$ January 2014).

Fang, E., Palmatier, R. and Steenkamp, J. (2008), "Effect of service transition strategies on firm value", Journal of Marketing, Vol. 72 No. 4, pp. 1-14.

Field, A. (2009). Discovering statistics using SPSS (3rd ed.), Sage, Thousand Oaks, California.

Galbraith, J. (2002). “Organizing to deliver solutions”, Organizational Dynamics, Vol. 31, pp. 194-207.

Gebauer, H. (2007), “An investigation of antecedents for the development of customer support services in manufacturing companies", Journal of Business-to-Business Marketing, Vol. 13 No. 3, pp. 59-96.

Gebauer, H., Edvardsson, B., Gustafsson, A. and Witell, L. (2010), "Match or mismatch: strategy configurations in the service business of manufacturing companies", Journal of Service Research, Vol. 13 No. 2, pp. 198-215.

Gebauer, H. and Fleisch, E. (2007), "An investigation of the relationship between behavioral processes, motivation, investments in the service business and service revenue", Industrial Marketing Management, Vol. 36 No. 3, pp. 337-348.

Gebauer, H., Fleisch, E. and Friedli, T. (2005), "Overcoming the service paradox in manufacturing companies", European Management Journal, Vol. 23 No. 1, pp. 1426.

Gebauer, H., Friedli, T. and Fleisch, E. (2006), "Success factors for achieving high service revenues in manufacturing companies", Benchmarking. An International Journal, Vol. 13 No. 3, pp. 374-386.

Gebauer, H., Gustafsson, A. and Witell, L. (2011), "Competitive advantage through service differentiation by manufacturing companies”, Journal of Business Research, Vol. 64 No. 12, pp. 1270-1280. 
Accepted as: Raddats, C., Burton, J. and Ashman, R. (2015) "Resource configurations for services success in manufacturing companies", Journal of Service Management, 26 (1), 97116. Available at: http://www.emeraldinsight.com/toc/josm/26/1 (accessed on 09/02/2015). DOI: 10.1108/JOSM-12-2012-0278.

Gebauer, H., Paiola, M. and Saccani, N. (2013), "Characterizing service networks for moving from products to solutions", Industrial Marketing Management, Vol. 42 Iss. 1, pp. 3146.

Gebauer, H., Putz, F., Fischer, T. and Fleisch, E. (2009), "Service orientation of organizational structures", Journal of Relationship Marketing, Vol. 8 No. 2, pp. 103126.

Gounaris, S. (2005), “Trust and commitment influences on customer retention: Insights from business-to-business services", Journal of Business Research, Vol. 50 No. 2, pp. 126140.

Grönroos, C. (1984), “A service quality model and its marketing implications”, European Journal of Marketing, Vol. 18 No. 4, pp. 36-44.

Grönroos, C. (2012), "Conceptualising value co-creation: A journey to the 1970s and back to the future", Journal of Marketing Management, Vol. 28 No.13/14, pp.1520-1534.

Grönroos, C. and Helle, P. (2010), “Adopting a service logic in manufacturing. Conceptual foundations and metrics for mutual value creation", Journal of Service Management, Vol. 21 No. 5, pp. 564-590.

Hair, J., Black, W., Babin, B., Anderson, R. and Tatham, R. (2006). Multivariate Data Analysis (6th ed.), Pearson Prentice Hall, Upper Saddle River, New Jersey.

Hansen, H., Samuelsen, B. and Silseth, P. (2008), "Customer perceived value in b2b service relationships: Investigating the importance of corporate reputation”, Industrial Marketing Management, Vol. 37 No. 2, pp. 206-217.

Hatcher, L. (1994), A step-by-step approach to using SAS for factor analysis and structural equation modelling, SAS Institute, Cary, NC.

Heinonen, K., Strandvick, T., Mickelsson, K-J., Edvardsson, B., Sundstrom, E. and Andresson, P. (2010), “A customer-dominant logic of service." Journal of Service Management, Vol. 21 No.4, pp.531-548.

Henneberg, S., Gruber, S. and Naudé, P. (2013), "Service networks: Concepts and research agenda”, Industrial Marketing Management, Vol. 42 Iss. 1, pp. 3-8.

Holmström, J., Brax, S. and Ala-Risku, T. (2010), "Comparing provider-customer constellations of visibility-based service", Journal of Service Management, Vol. 21 Iss. 5, pp.675-692.

Homburg, C., Fassnacht, M. and Guenther, C. (2003), "The role of soft factors in implementing a service-orientated strategy in industrial marketing companies", Journal of Business-to-Business Marketing, Vol. 10 No. 2, pp. 23-51.

Homburg, C., Workman, J. and Krohmer, H. (1999), "Marketing’s influence within the firm”, Journal of Marketing, Vol. 63, pp. 1-17.

$\mathrm{Hu}$, L. and Bentler, P. (1999), "Cut off criteria for fit indexes in covariance structure analysis: Conventional criteria versus new alternatives", Structural Equation Modelling: A Multidisciplinary Journal, Vol. 6 No. 1, pp. 1-55. 
Accepted as: Raddats, C., Burton, J. and Ashman, R. (2015) "Resource configurations for services success in manufacturing companies”, Journal of Service Management, 26 (1), 97116. Available at: http://www.emeraldinsight.com/toc/josm/26/1 (accessed on 09/02/2015). DOI: $10.1108 / J O S M-12-2012-0278$.

Hunt, S., Arnett, D. and Madhavaram, S. (2006), "The explanatory foundations of relationship marketing theory", Journal of Business \& Industrial Marketing, Vol. 21 No. 2, pp. 72-87.

Hunt, S. and Morgan, R. (1995), "The comparative advantage theory of competition", Journal of Marketing, Vol. 59, pp. 1-15.

Jacob, F. and Ulaga, W. (2008), "The transition from product to service in business markets: An agenda for academic inquiry", Industrial Marketing Management, Vol. 37 No. 3, pp. 247-253.

Johnstone, S., Dainty, A. and Wilkinson, A. (2009), "Integrating products and services through life: An aerospace experience", International Journal of Operations \& Production Management, Vol. 29 No. 5, pp. 520-528.

Keh, H. and Xie, Y. (2008), "Corporate reputation and customer behavioral intentions: The roles of trust, identification and commitment", Industrial Marketing Management, Vol. 38 No. 7, pp. 732-742.

Kindström, D. and Kowalkowski, C. (2014), "Service innovation in product-centric firms: a multinational business model perspective", Journal of Business and Industrial Marketing, Vol. 29 Iss. 2, pp. 96-111.

Kinnunen, R-E. and Turunen, T. (2012), "Identifying servitization capabilities of manufacturers: A conceptual framework", The Journal of Applied Management and Entrepreneurship, Vol. 17 No. 3, pp. 55-74.

Lee, Y-C. and Lee, S-K. (2007), "Capabilities, processes, and performance of knowledge management: A structural approach", Human Factors and Ergonomics in Manufacturing, Vol. 17 No. 1, pp. 21-41.

Lindell, M. and Whitney, D. (2001), "Accounting for common method variance in crosssectional research designs", Journal of Applied Psychology, Vol. 86 No. 1, pp. 114121.

Madhavaram, S. and Hunt, S. (2008), "The service-dominant logic and a hierarchy of operant resources: Developing masterful operant resources and implications for marketing strategy", Journal of Academy Marketing Science, Vol. 36, pp. 67-82.

Mathieu, V. (2001), "Product services: from a service supporting the product to a service supporting the client", Journal of Business \& Industrial Marketing, Vol. 36 No. 1, pp. $39-58$.

Morgan, R. and Hunt, S. (1994), "The commitment-trust theory of relationship marketing", Journal of Marketing, Vol. 58 No. 3, pp. 20-38.

Neu, W. and Brown, S. (2005), "Forming successful business-to-business services in goodsdominated firms", Journal of Service Research, Vol. 8 No. 1, pp. 3-17.

Nordin, F. and Kowalkowski, C. (2010), "Solutions offerings: a critical review and reconceptualisation”. Journal of Service Management, Vol. 21 Iss. 4, pp. 441-459.

Nunnally, J. (1978), Psychometric theory (2nd ed.), McGraw-Hill, New York. 
Accepted as: Raddats, C., Burton, J. and Ashman, R. (2015) "Resource configurations for services success in manufacturing companies", Journal of Service Management, 26 (1), 97116. Available at: http://www.emeraldinsight.com/toc/josm/26/1 (accessed on 09/02/2015). DOI: 10.1108/JOSM-12-2012-0278.

Oliva, R., Gebauer, H. and Brann, J. (2012), "Separate or Integrate? Assessing the impact of separation between product and service business on service performance in product manufacturing firms", Journal of Business-to-Business Marketing, Vol. 19 Iss. 4, pp. 309-334.

Oliva, R. and Kallenberg, R. (2003), "Managing the transition from product to services", International Journal of Service Industry Management, Vol. 14 No. 2, pp. 160-172.

Ostrom, A., Bitner, M., Brown, S., Burkhard, K., Goul, M., Smith-Daniels, V., Demirkan, H. and Rabinovich, E. (2010), "Moving forward and making a difference: Research priorities for the science of service", Journal of Service Research, Vol. 13 No. 1, pp. 4-36.

Paiola, M., Saccani, N., Perona, M. and Gebauer, H. (2013), "Moving from products to solutions: Strategic approaches for developing capabilities", European Management Journal, Vol. 31 Iss. 4, pp. 390-409.

Pallant, J. (2007), SPSS survival manual (3rd ed.), Open University Press, Maidenhead (UK).

Paxson, C. (1992), “Follow-up mail surveys”, Industrial Marketing Management, Vol. 21 Iss. 3, pp. 195-201.

Raddats, C. and Burton, J. (2014), “Creating multi-vendor solutions: The resources and capabilities required”, Journal of Business and Industrial Marketing, Vol. 29 Iss. 2, pp. 132-142.

Raddats, C. and Easingwood, C. (2010), "Services growth options for B2B product-centric businesses”, Industrial Marketing Management, Vol. 39 No. 8, pp. 1331-1342.

Rauyruen, P. and Miller, K. (2007), "Relationship quality as a predictor of B2B customer loyalty", Journal of Business Research, Vol. 60, pp. 21-31.

Sawhney, M. (2006), "Going beyond the product, defining, designing, and delivering customer solutions", in Lusch, R. and Vargo, S. (Eds.), The service-dominant logic of marketing: Dialog, debate, and directions, M.E. Sharp, New York, pp. 365-380.

Schumaker, R. and Lomax, R. (2010) A beginners guide to structural equation modelling (3rd ed.), Routledge, London.

Steiger, J. (2007), "Understanding the limitations of global fit assessment in structural equation modeling," Personality and Individual Differences, Vol. 42 No. 5, pp. 89398.

Storbacka, K. (2011), “A solution business model: Capabilities and management practices for integrated solutions”, Vol. 40 Iss. 5, pp. 691-711.

Ulaga, W. and Reinartz, W. (2011), "Hybrid offerings: How manufacturing firms combine goods and services successfully", Journal of Marketing, Vol. 75 No. 6, pp. 5-23.

UK Standard Industrial Classification (SIC) of Economic Activities (2003), available at: http://www.businessballs.com/industrialclassifications.htm (accessed 14th November 2012).

Vandaele, D. and Gemmel, P. (2004), "Development of an assessment scale for business-tobusiness service quality: Assessment in the facility services sector", available at: 
Accepted as: Raddats, C., Burton, J. and Ashman, R. (2015) "Resource configurations for services success in manufacturing companies", Journal of Service Management, 26 (1), 97116. Available at: http://www.emeraldinsight.com/toc/josm/26/1 (accessed on 09/02/2015). DOI: 10.1108/JOSM-12-2012-0278.

http://www.feb.ugent.be/nl/Ondz/wp/Papers/wp_04_259.pdf (accessed 11th November 2012).

Vandermerwe, S. and Rada, J. (1988), "Servitization of business: Adding value by adding services", European Management Journal, Vol. 6 No. 4, pp. 314-324.

Vargo, S. and Lusch, R. (2008), "From goods to service(s): Divergences and convergences of logics", Industrial Marketing Management, Vol. 37 No. 3, pp. 254-259.

Windahl, C., Andersson, P., Berggren, C. and Nehler, C. (2004), "Manufacturing firms and integrated solutions: Characteristics and implications", European Journal of Innovation Management, Vol. 7 No. 3, pp. 218-228.

Wise, R. and Baumgartner, P. (1999), "Go downstream: the new profit imperative in manufacturing”, Harvard Business Review, Vol. 77 Iss. 5, pp. 133-141. 
Accepted as: Raddats, C., Burton, J. and Ashman, R. (2015) "Resource configurations for services success in manufacturing companies", Journal of Service Management, 26 (1), 97116. Available at: http://www.emeraldinsight.com/toc/josm/26/1 (accessed on 09/02/2015). DOI: 10.1108/JOSM-12-2012-0278.

\section{Appendix A - Sector information for the completed sample}

\begin{tabular}{|ll|}
\hline UK SIC (2003) classification (code) & $\begin{array}{l}\text { Number of } \\
\text { companies in } \\
\text { completed sample }\end{array}$ \\
\hline Extraction of crude petroleum and natural gas (11) & 1 \\
Other mining and quarrying (14) * & 3 \\
Publishing and printing (22)* & 3 \\
Manufacture of chemicals and chemical products (24) * & 11 \\
Manufacture of rubber and plastic products (25) & 5 \\
Manufacture of other non-metallic mineral products (26) & 3 \\
Manufacture of basic metals (27) * & 4 \\
Manufacture of fabricated metal products (28) & 24 \\
Manufacture of machinery and equipment not elsewhere classified (29) * & 25 \\
Manufacture of office machinery and computers (30) * & 15 \\
Manufacture of electrical machinery and apparatus (31) * & 9 \\
Manufacture of radio, television and communication equipment (32)* & 11 \\
Manufacture of medical, precision and optical instruments (33) * & 10 \\
Manufacture of motor vehicles (34) & 2 \\
Manufacture of other transport equipment (35) * & 8 \\
Other sectors & 21 \\
\hline TOTAL & $\mathbf{1 5 5}$ \\
\hline
\end{tabular}

* Managers from these sectors were involved in pre-survey interviews 